\title{
Poziom wiedzy z zakresu czynników ryzyka i profilaktyki raka piersi wśród studentek wroctawskich uczelni
}

\section{Knowledge of risk factors and prevention of breast cancer among female university students in Wroclaw}

\author{
Iwona Malicka ${ }^{\bowtie}$, Marta Jelecka
}

Akademia Wychowania Fizycznego we Wrocławiu, Zakład Fizjoterapii w Medycynie Zabiegowej i Onkologii, al. I.J. Paderewskiego 35, 51-612 Wrocław University School of Physical Education in Wroclaw, Department of Physiotherapy in Occupational Medicine and Oncology

$\triangle$ iwona.malicka@awf.wroc.pl

\begin{abstract}
Introduction: The research so far shows that despite many worldwide and national campaigns, women's knowledge about breast cancer is still insufficient or not used in practice.

The purpose of the study was to evaluate the knowledge of breast cancer risk factors and preventive measures among young women (female students).

Materials and methods: The study group consisted of 320 female students, respondents from University School of Physical Education in Wroclaw (USPEW), Wroclaw University of Science and Technology, University of Wroclaw, and Wroclaw Medical University (WMU). The study was questionnaire-based. The results of the survey have been analyzed in terms of the female respondents' place of residence, and depending on the higher education institutions

Results: The place of residence does not have an impact on the awareness and knowledge of the female students in respect of
\end{abstract}

breast cancer risk factors and preventive measures. The majority of female students are acquainted with breast cancer risk factors. The female students from the WMU and USPEW in particular had the greatest knowledge in this respect. The female students did not have their breasts examined at the doctor's office. Moreover, in most cases they do not self-examine their breasts, or they do it irregularly. The female students derive their knowledge about breast cancer risk factors and preventive measures mainly from media and the press.

Conclusions: In general, the female students know the symptoms of breast cancer; however, the knowledge depends on the university profile. Theoretical knowledge was not used in practice. Regardless of the university profile, respondents reported the need for campaigns to fight cancer in Poland.

Keywords: breast cancer; prevention; risk factors; knowledge; social campaigns.

\begin{abstract}
ABSTRAKT
Wstęp: Dotychczasowe badania wskazują, że mimo wielu kampanii informacyjnych na temat raka piersi wiedza kobiet w tym zakresie jest niewystarczająca lub niewykorzystywana w praktyce.

Celem pracy była ocena wiedzy młodych kobiet (studentek) z zakresu czynników ryzyka i profilaktyki raka piersi.

Materiały i metody: W badaniach uczestniczyło 320 studentek, respondentek z Akademii Wychowania Fizycznego we Wrocławiu (AWF), Politechniki Wrocławskiej, Uniwersytetu Wrocławskiego oraz Uniwersytetu Medycznego im. Piastów Śląskich we Wrocławiu (UM). Narzędziem badawczym był kwestionariusz ankiety. Analiza uwzględniała miejsce zamieszkania oraz rodzaj uczelni. Wyniki: Miejsce zamieszkania nie wpływało na poziom wiedzy studentek w zakresie czynników ryzyka i profilaktyki raka piersi. Studentki w większości znały czynniki ryzyka raka piersi
\end{abstract}

oraz jego objawy. Większą wiedzą w tym zakresie wykazały się studentki UM oraz AWF. Studentki z reguły nie miały wykonywanego badania piersi u lekarza, w większości nie dokonywały także samobadania piersi bądź robiły je nieregularnie. Najczęściej młode kobiety czerpały wiedzę na temat czynników ryzyka i profilaktyki raka piersi z mediów i prasy.

Wnioski: Poziom wiedzy z zakresu czynników ryzyka i profilaktyki raka piersi wśród studentek wrocławskich uczelni można uznać za zadowalający, uzależniony był on jednak od wybranego kierunku studiów. Wiedza teoretyczna nie była wykorzystywana w praktyce. Niezależnie od profilu uczelni respondentki zgłosiły potrzebę prowadzenia kampanii na rzecz walki $\mathrm{z}$ rakiem $\mathrm{w}$ Polsce.

Słowa kluczowe: rak piersi; profilaktyka; czynniki ryzyka; stan wiedzy; kampanie społeczne.

\section{WSTEP}

Zmiany w strukturze demograficznej ludzkiej populacji spowodowały, że obecnie głównym wyzwaniem medycyny stają się choroby przewlekłe, w tym nowotwory. Na świecie odnotowuje się ponad $14 \mathrm{mln}$ zachorowań na nowotwory rocznie oraz ponad 8 mln zgonów z tego powodu [1]. W ostatnich latach stanowią one także jedną z głównych przyczyn przedwczesnej śmierci. Zjawisko to jest szczególnie widoczne wśród kobiet przed 65. r.ż. Obecnie nowotwory są najczęstszą przyczyną zgonów młodych kobiet (34\%) oraz kobiet w średnim wieku (48\%) [2]. 
Najczęściej występującym nowotworem u kobiet jest rak piersi [3]. W 2012 r. zdiagnozowano go u 1,7 mln kobiet na świecie. Najwyższy wskaźnik zachorowalności obserwuje się w krajach o wysokim stopniu rozwoju ekonomicznego, są to kraje Europy Zachodniej, Ameryki Północnej, a także Australii i Nowej Zelandii [4]. Polska należy do krajów o średniej zachorowalności na raka piersi, jednak badania epidemiologiczne wskazują na tendencję wzrostową. Obecnie rak piersi stanowi $20 \%$ wszystkich nowotworów złośliwych u Polek [5]. Ciągły wzrost zachorowalności jest poważnym zagrożeniem dla życia i zdrowia kobiet.

W większości krajów, w których występuje problem dotyczący nowotworów, prowadzone są kampanie propagujące zdrowy tryb życia i programy edukacyjne odnoszące się do czynników ryzyka i profilaktyki nowotworowej. Podnoszenie świadomości prozdrowotnej dotyczącej udowodnionych czynników ryzyka zachorowania na raka piersi stanowi ważny element prewencji pierwotnej choroby [6]. W Polsce, tak jak na świecie, od kilku lat realizowane są kampanie społeczne oraz program wczesnego wykrywania raka piersi. Kobiety powinny zdawać sobie sprawę, że wczesne wykrycie przypadku choroby nowotworowej i wdrożenie odpowiedniego leczenia może uratować im życie. Na podstawie aktualnego stanu realizacji i wykorzystania badań przesiewowych z zakresu prewencji nowotworów piersi wyraźnie widać jednak, że ochrona zdrowia w Polsce stoi przed poważnym problemem, jakim jest brak zainteresowania populacji dbałością o własne zdrowie. Większa część kobiet odkłada badania na później, część nie interesuje się nimi, a jeszcze inne bagatelizują problem, gdyż uważają, że ich nie dotyczy [7].

Celem pracy była ocena wiedzy studentek wrocławskich uczelni na temat czynników ryzyka i profilaktyki raka piersi.

\section{MATERIAŁY I METODY}

Grupę badaną stanowiło 320 kobiet, studentek z czterech wrocławskich uczelni; $80 \mathrm{z}$ nich studiowało na Akademii Wychowania Fizycznego we Wrocławiu (AWF), były to przedstawicielki wiedzy o zdrowiu i kulturze fizycznej, 80 na Politechnice Wrocławskiej (PWr) - przedstawicielki kierunków ścisłych, 80 na Uniwersytecie Wrocławskim (UWr) - przedstawicielki kierunków humanistycznych oraz 80 na Uniwersytecie Medycznym im. Piastów Śląskich we Wrocławiu (UM) - przedstawicielki nauk medycznych. Średnia wieku respondentek wyniosła $22,48 \pm 1,62$ lata i były to przede wszystkim studentki 5 . roku (45,3\%), pochodzące najczęściej z terenów miejskich. Mieszkanki wsi stanowiły 13,7\%, miasta do 10 tys. mieszkańców 6,6\%, miasta $10-100$ tys. mieszkańców - 22,5\%, miasta 100500 tys. mieszkańców $-10,9 \%$ oraz miasta powyżej 500 tys. mieszkańców - 46,3\%.

Badanie przeprowadzono metodą sondażu diagnostycznego za pomocą autorskiej ankiety. Kwestionariusz zawierał pytania dotyczące sytuacji społeczno-demograficznej oraz pytania sprawdzające wiedzę na temat profilaktyki i czynników ryzyka raka piersi.
Analizę statystyczną wykonano za pomocą programu Statistica. Przeprowadzono analizę opisową. Ponadto w celu zbadania zależności pomiędzy poszczególnymi zmiennymi zastosowano test niezależności $\chi^{2}$. Za wynik istotny statystycznie przyjęto wartość $\mathrm{p}<0,05$.

\section{WYNIKI}

Wiedza na temat raka piersi wśród studentek wrocławskich uczelni została przeanalizowana pod względem miejsca zamieszkania respondentek oraz w zależności od profilu uczelni. W przypadku miejsca zamieszkania nie wykazano istotnych różnic, uznano zatem, że miejsce zamieszkania nie wpływa na poziom wiedzy studentek. W przypadku uczelni wykazano istotne statystycznie różnice.

Poprawną znajomością czynników ryzyka raka piersi wykazały się przede wszystkim studentki UM oraz AWF. Brak takiej wiedzy zgłosiło natomiast 18,8\% studentek PWr oraz 18,8\% studentek UWr. Struktura odpowiedzi respondentek różniła się istotnie w odniesieniu do następujących czynników ryzyka: spożywanie alkoholu $(\mathrm{p}=0,02)$, palenie papierosów $(\mathrm{p}<0,01)$, nieodpowiednia dieta $(\mathrm{p}<0,01)$, otyłość $(\mathrm{p}<0,01)$, bezdzietność/pierwszy poród po 30. r.ż. (p <0,01), brak karmienia piersią $(\mathrm{p}<0,01)$, wczesna pierwsza miesiączka $(\mathrm{p}<0,01)$, późna menopauza $(\mathrm{p}<0,01)$, mutacja genu BRCA1/BRCA2 $(\mathrm{p}<0,01)$ oraz narażenie na promieniowanie $(\mathrm{p}<0,01)$ - rycina 1 .

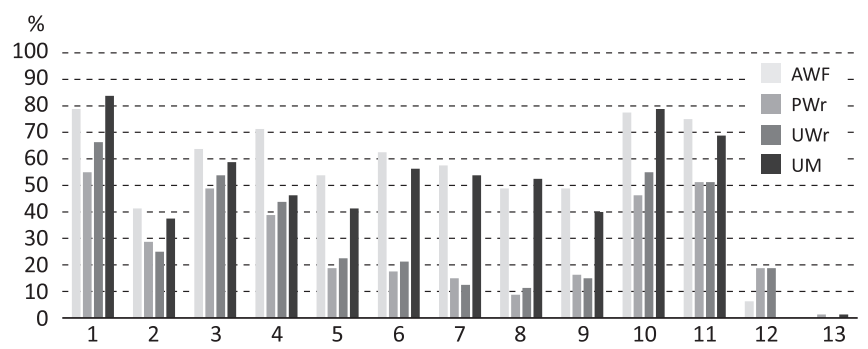

1 - wiek po 50. r.ż.; 2 - spożywanie alkoholu; 3 - palenie papierosów; 4 nieodpowiednia dieta; 5 - otyłość; 6 - bezdzietność/pierwszy poród po 30. r.ż.; 7 - brak karmienia piersią; 8 - wczesna pierwsza miesiączka; 9 - późna menopauza; 10 - mutacja genu BRCA1/BRCA2; 11 - narażenie na promieniowanie; 12 - nie wiem; 13 - nie ma takich czynników

RYCINA 1. Procentowy rozkład odpowiedzi na pytanie dotyczące czynników ryzyka raka piersi z podziałem na poszczególne uczelnie

Respondentki znały w większości objawy raka piersi, niemniej jednak w przypadku następujących odpowiedzi wykazano różnice istotne statystycznie: ból bez uchwytnych przyczyn $(p=0,002)$, obrzęk skóry $(p<0,01)$, wyczuwalny guzek przy palpacji $(\mathrm{p}<0,01)$, zmiany na skórze, np. owrzodzenie brodawki $(p<0,01)$, wyciek treści z brodawki $(p<0,01)$, wciągnięcie brodawki $(\mathrm{p}<0,01)$, obraz skórki pomarańczy $(\mathrm{p}<0,01)$, miejscowa zmiana w wyglądzie piersi, np. asymetria sutków, zaczerwienienie $(\mathrm{p}<0,01)$, wzrost temperatury ciała $(\mathrm{p}<0,01)$, powiększenie węzłów chłonnych $(\mathrm{p}<0,01)$, świąd/pieczenie brodawki $(\mathrm{p}<0,01)$, nie wiem $(\mathrm{p}<0,01)$ - rycina 2 .

Większość studentek (59,7\%), niezależnie od profilu uczelni, poprawnie udzieliła odpowiedzi na pytanie dotyczące wieku 


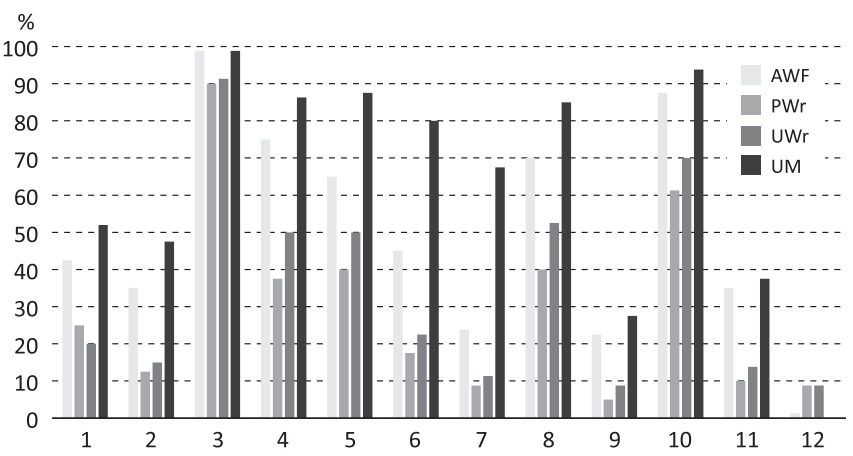

1 - ból bez uchwytnych przyczyn; 2 - obrzęk skóry; 3 - wyczuwalny guzek przy palpacii; 4 - zmiany na skórze; 5 - wyciek treści z brodawki; 6 - wciągnięcie brodawki; 7 - obraz skórki pomarańczy; 8 - miejscowa zmiana w wyglądzie piersi; 9 - wzrost temperatury ciała; 10 - powiększenie węzłów chłonnych; 11 - świąd/ pieczenie brodawki; 12 - nie wiem

RYCINA 2. Procentowy rozkład odpowiedzi na pytanie dotyczące możliwych objawów raka piersi w podziale na poszczególne uczelnie

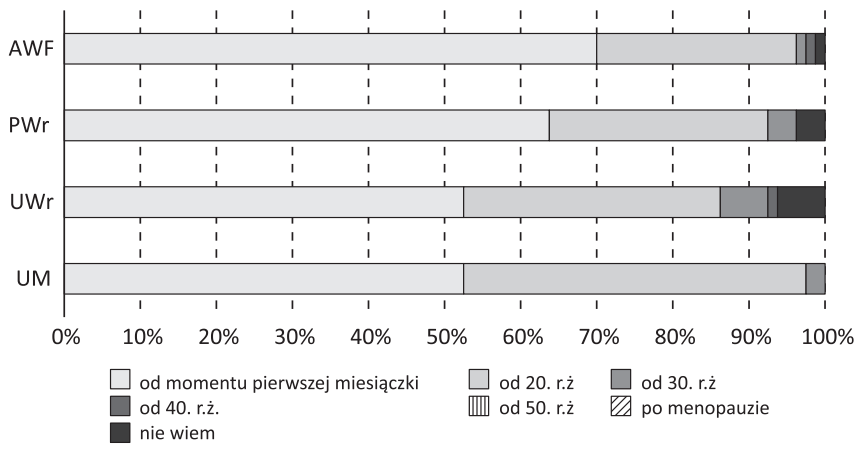

RYCINA 3. Procentowy rozkład odpowiedzi na pytanie dotyczące wieku rozpoczęcia samobadania piersi w podziale na poszczególne uczelnie

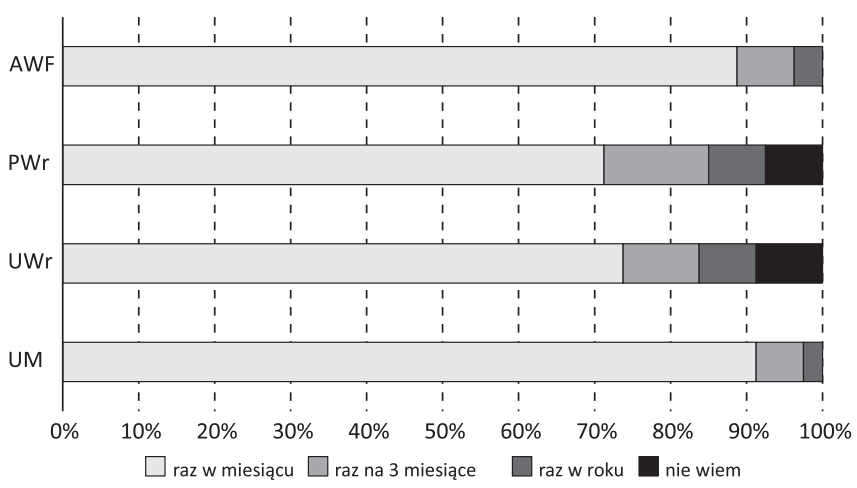

RYCINA 4. Procentowy rozkład odpowiedzi na pytanie dotyczące częstotliwości wykonywania samobadania piersi w podziale na poszczególne uczelnie

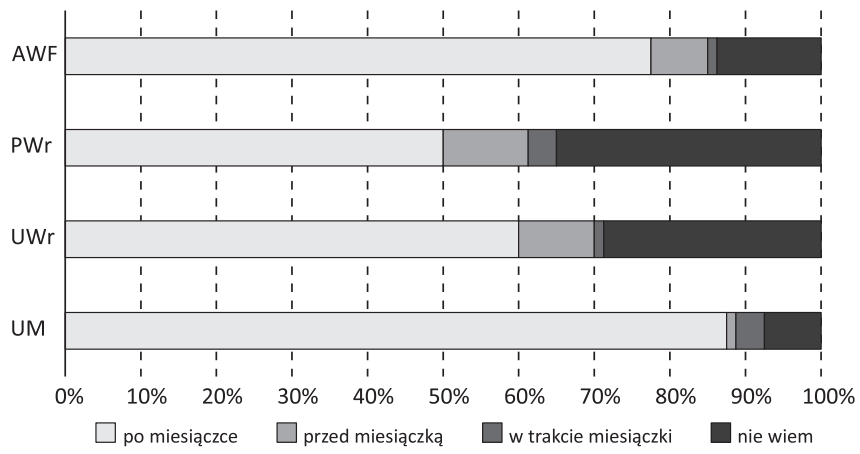

RYCINA 5. Procentowy rozkład odpowiedzi na pytanie dotyczące czasu, w którym powinno się wykonywać samobadanie piersi w podziale na poszczególne uczelnie rozpoczęcie samobadania piersi (ryc. 3). Studentki w zdecydowanej większości $(81,2 \%)$ posiadały także wiedzę dotyczącą tego, jak często powinno się wykonywać samobadanie piersi, aczkolwiek struktura odpowiedzi nie była jednorodna. Wynik okazał się istotny statystycznie na poziomie $\mathrm{p}=0,009$, a różnicę zaobserwowano w odpowiedziach udzielanych przez studentki AWF i UM w stosunku do studentek z PWr i UWr (ryc. 4). Istotne statystycznie różnice zaobserwowano także w wiedzy na temat prawidłowego badania piersi w odniesieniu do odpowiedzi: wykonywane jest w pozycji siedzącej/leżącej $(\mathrm{p}<0,01)$, wykonywane jest przed lustrem $(\mathrm{p}<0,01)$, jest to obserwacja piersi ze zwróceniem szczególnej uwagi na symetrię piersi, wygląd skóry, wygląd brodawki sutkowej i jej otoczki $(p<0,01)$ oraz jest to badanie dotykowe całej piersi węzłów chłonnych w okolicach dołów pachowych oraz nad i pod obojczykiem ( $\mathrm{p}<0,01)$. Struktura odpowiedzi była istotnie różna także w przypadku odpowiedzi na pytanie dotyczące fazy cyklu menstruacyjnego, w której należy wykonywać samobadanie piersi $(p<0,01)$. Najwięcej poprawnych odpowiedzi udzieliły studentki z UM (ryc. 5).

Samobadania piersi nie wykonywało 50\% ogółu respondentek. Spośród czterech uczelni tylko studentki z UM w ponad połowie odpowiedziały pozytywnie $(\mathrm{p}=0,006)$ - rycina 6 . Samobadanie piersi, nawet w przypadku jego wykonywania nie było regularne. Zgodnie z zaleceniami - raz w miesiącu wykonywało je tylko 30\% studentek UM, 20\% AWF, 15\% PWr oraz 12,5\% UWr. Odpowiedzi różniły się istotnie na poziomie $\mathrm{p}=0,02$ (ryc. 7).

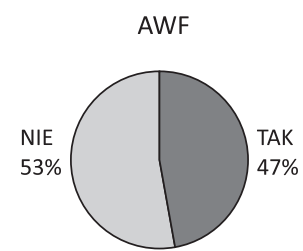

UWr

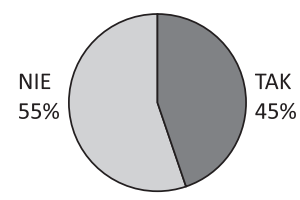

$\mathrm{PWr}$

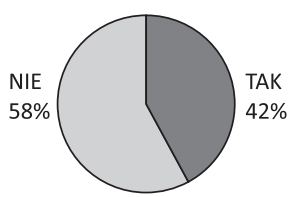

UM

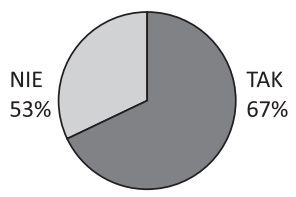

RYCINA 6. Procentowy rozkład odpowiedzi na pytanie: Czy wykonuje Pani samobadanie piersi? - w podziale na poszczególne uczelnie

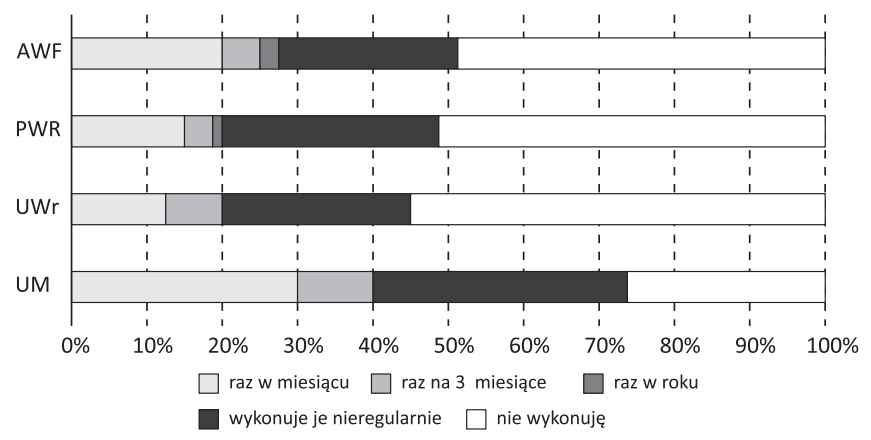

RYCINA 7. Procentowy rozkład odpowiedzi na pytanie dotyczące częstotliwości wykonywania przez respondentki samobadania piersi w podziale na poszczególne uczelnie 
W pytaniu wielokrotnego wyboru o diagnostykę raka piersi u młodszych kobiet dominowały poprawne odpowiedzi. Większość respondentek wskazała USG piersi oraz badania palpacyjne prowadzone przez ginekologa. Obie odpowiedzi różniły się jednak istotnie w zależności od profilu uczelni p < 0,01 (ryc. 8). W przypadku wskazania wieku dla wykonania pierwszej mammografii dominowały odpowiedzi: po 40. r.ż. (31,6\% ogółu respondentek) oraz po 50. r.ż. (25,3\% ogółu badanych). Odpowiedzi różniły się istotnie $(\mathrm{p}<0,01)$ w zależności od profilu uczelni. Zgodny z zaleceniami wiek został wskazany przede wszystkim przez respondentki UM, w dalszej kolejności przez studentki AWF, PWr, a następnie UWr (ryc. 9).

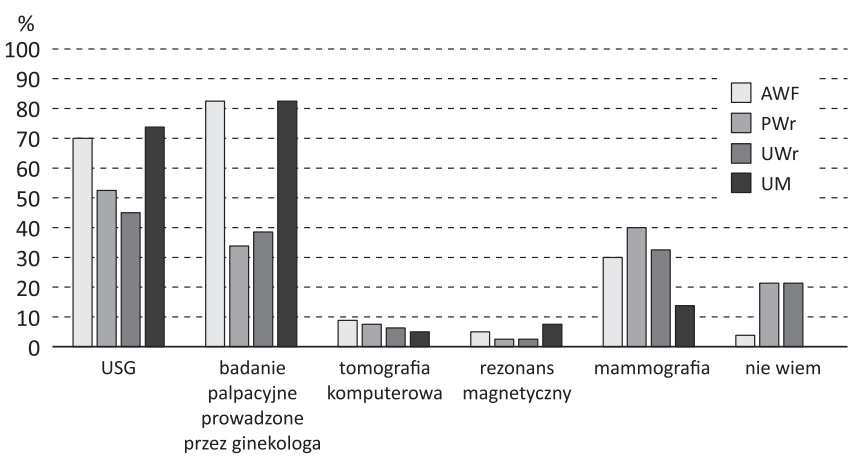

RYCINA 8. Procentowy rozkład odpowiedzi na pytanie dotyczące diagnostyki raka piersi młodszych kobiet w podziale na poszczególne uczelnie

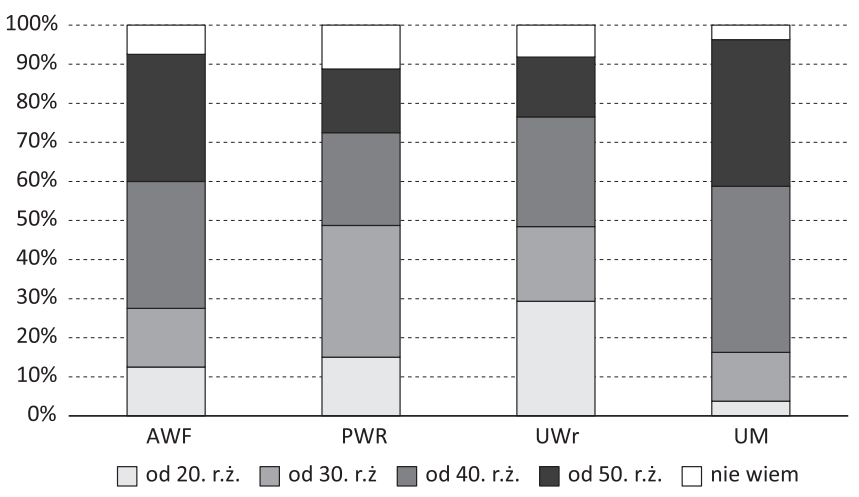

RYCINA 9. Procentowy rozkład odpowiedzi na pytanie dotyczące wieku wykonywania badania mammograficznego w podziale na poszczególne uczelnie

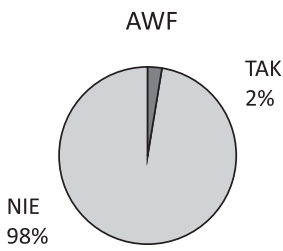

UWr

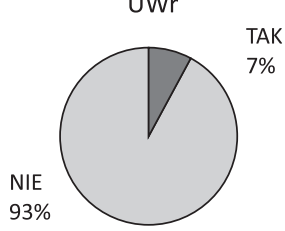

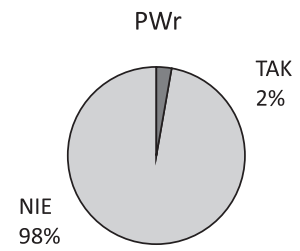

UM

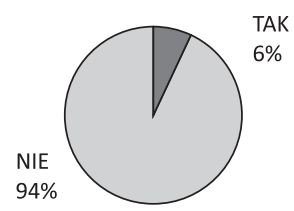

RYCINA 10. Procentowy rozkład odpowiedzi na pytanie: Czy bierze Pani udział w programach profilaktycznych raka piersi? w podziale na poszczególne uczelnie
Nie wykazano istotnych różnic w odpowiedzi na pytanie odnoszącego się do badań palpacyjnych prowadzonych przez lekarza ginekologa. Nigdy nie było badanych 35,9\% ogółu respondentek, natomiast 22,5\% zazwyczaj nie miało wykonywanych badań palpacyjnych piersi podczas wizyty u ginekologa.

Respondentki, niezależnie od profilu uczelni, raczej nie brały udziału w programach profilaktycznych (ryc. 10). Studentki czerpały swoją wiedzę dotyczącą profilaktyki i leczenia raka piersi przede wszystkim z mediów (prasa - 75,6\%, internet $63,1 \%$, telewizja - 46,9\%). Niezależnie od profilu uczelni respondentki zgłosiły potrzebę prowadzenia kampanii na rzecz walki $\mathrm{z}$ rakiem w Polsce.

\section{DYSKUSJA}

Jednym z najistotniejszych czynników mających wpływ na zmniejszenie zachorowalności i umieralności na raka piersi jest profilaktyka onkologiczna obejmująca zarówno prewencję pierwotną, jak i wtórną. Edukacja onkologiczna kobiet powinna więc stanowić obecnie najważniejszy element kształtujący przekonania i zachowania zdrowotne w populacji ludzkiej. Aby zwiększyć udział kobiet w podejmowaniu działań na rzecz własnego zdrowia, należy odnieść się do ich wiedzy i kształtować w nich poczucie odpowiedzialności za siebie i swoich najbliższych $[6,8]$.

Znajomość czynników ryzyka zachorowania na raka piersi jest jednym z ważnych elementów przyjęcia odpowiedniego stylu życia, mającego na celu zmniejszenie narażenia na czynniki kancerogenne [9]. Na podstawie przeprowadzonej ankiety wykazano, iż respondentki UM oraz AWF posiadały lepszą wiedzę na temat czynników ryzyka raka piersi w porównaniu z respondentkami PWr oraz UWr. Ich wiedza na temat czynników zachorowania na raka piersi była dokładniejsza, gdyż nie tylko znały one podstawowe czynniki, takie jak: wiek po 50. r.ż., palenie papierosów czy spożywanie alkoholu, ale również były świadome, że otyłość, nieodpowiednia dieta, bezdzietność, wczesna miesiączka, późna menopauza czy mutacje genów BRCA1/BRCA2 również w znacznym stopniu mogą wpłynąć na rozwój choroby. Profil uczelni miał więc znaczny wpływ na poziom powyższej wiedzy. W przeglądzie piśmiennictwa wykazano również zróżnicowany poziom znajomości czynników ryzyka raka piersi. Poziom świadomości zdrowotnej wśród studentek w badaniach Wołowskiego i Wróblewskiej uznano za zadowalający. Ponad połowa $(55,2 \%)$ respondentek - studentek z Gdańska - potrafiła prawidłowo wskazać wszystkie czynniki ryzyka rozwoju raka piersi [10]. Wysoką wiedzę na temat czynników ryzyka raka piersi posiadali także studenci - niezależnie od płci - w badaniach Ridan i wsp. [11]. Natomiast Kalinowski i wsp. [12] wykazali trudność w określeniu czynników ryzyka raka piersi przez studentki Uniwersytetu Medycznego w Lublinie. Podobne wyniki przedstawili także Paździor i wsp. [13]; znajomość profilaktyki raka piersi wśród kobiet nie była w pełni zadowalająca i wymagała uzupełnienia.

Znajomość objawów mogących sugerować rozwój raka piersi jest jednym z najważniejszych elementów wpływających 
na szybką identyfikację niepokojących zmian w piersiach [6]. Studentki wrocławskich uczelni w większości znały objawy raka piersi. Najpopularniejszymi odpowiedziami były te najbardziej powszechnie związane z chorobą, czyli wyczuwalny guzek przy palpacji oraz powiększenie węzłów chłonnych. W tym wypadku jednak również uzyskano istotne różnice. Lepszą wiedzą wraz ze wskazaniem większej liczby objawów raka piersi wykazały się ponownie studentki UM i AWF. W przeglądzie piśmiennictwa wskazuje się jednak na małą wiedzę na temat chorób nowotworowych wśród kobiet. Woźniak stwierdziła, że ponad $56 \%$ badanych nie potrafiło wymienić nawet jednego objawu chorób nowotworowych u kobiet [14]. Podobnych spostrzeżeń dokonali także Zych i wsp. W tym wypadku z kolei co druga respondentka potrafiła wymienić tylko cztery z ośmiu objawów świadczących o wystąpieniu raka piersi [15] Taki stan wiedzy może świadczyć o małym przygotowaniu do samokontroli. W związku z powyższym wyraźnie widać, że nadal bardzo ważne jest prowadzenie edukacji w zakresie działań profilaktycznych na rzecz zdrowia. Działania z tego zakresu powinny być bardziej intensywne i bardziej oddziaływać na społeczeństwo.

Samobadanie piersi określa się często mianem nieinwazyjnego testu przesiewowego [16]. Jest to najtańsza i jednocześnie ważna metoda pozwalająca na wczesne wykrycie niepokojących zmian w piersiach. Ocenia się, że 90\% zmian złośliwych jest rozpoznawanych przez kobiety właśnie podczas samobadania [17]. Studentki w większości udzieliły prawidłowej odpowiedzi odnośnie do częstości, sposobu, a także okresu wykonywania samobadania piersi. W praktyce większość studentek, niezależnie od profilu uczelni, nie wykonywała jednak samobadania piersi lub wykonywała je nieregularnie. Jedynie studentki UM w $67 \%$ potwierdziły, że badały swoje piersi, aczkolwiek tylko $30 \% \mathrm{z}$ nich robiło to systematycznie raz w miesiącu. Jest to niepokojący fakt, ponieważ mimo znajomości czynników ryzyka oraz wiedzy na temat ważności tych badań młode kobiety nie praktykują samobadania piersi. Brak regularności w zakresie wykonywania samobadania piersi przez kobiety potwierdzili również Tkaczuk-Włach i wsp. [16], O’Malley i Fletcher [18] oraz Łepecka-Klusek i wsp. [19] i uznaje się, że jest to jeden z elementów ograniczających skuteczność tych badań.

Kolejna negatywna wiadomość wynikająca z przeprowadzonych badań dotyczyła tego, że studentki mimo wiedzy na temat badań zalecanych w diagnostyce młodych kobiet (badania palpacyjne, USG piersi) w większości nie miały ich wykonywanych u lekarza. Powyższy problem zauważyli także inni autorzy. Ślusarska i wsp. wykazali, że 61,1\% respondentek była świadomych tego, że ginekolog powinien przeprowadzać badanie gruczołów piersiowych przy każdej wizycie lekarskiej, jednak zaledwie 3,5\% przyznało, że lekarz robił to za każdym razem. Z kolei aż 60,4\% ankietowanych nigdy nie miało wykonanego badania palpacyjnego piersi przez specjalistę [6]. Podobne wyniki uzyskali także Lewandowska i wsp. Według $62 \%$ respondentek lekarz nigdy nie badał ich gruczołów piersiowych [8].

W profilaktyce ważną metodą postępowania jest także skrining mammograficzny. Prawidłowo zaplanowany program badań przesiewowych może zmniejszyć umieralność nawet o 15-35\% [20]. Znajomość wieku, w którym należy wykonywać badanie mammograficzne, okazała się jednak niewystarczająca w przypadku studentek PWr i UWr. Z kolei wiele respondentek studiujących na AWF i UM oprócz wieku po 50. r.ż. zaznaczało także odpowiedź: po 40. r.ż. Wynikać to może najprawdopodobniej z faktu, iż studentki te posiadały pogłębioną wiedzę na ten temat. Badania mammograficzne należy wykonywać regularnie po 50. r.ż., jednak w przypadku wskazań i indywidualnych zaleceń lekarza badanie to często wykonywane jest już od 40. r.ż.

Na uwagę zasługuje fakt, że studentki niezależnie od profilu uczelni nie brały udziału w programach profilaktycznych, mimo że w ostatnich latach temat, jakim jest rak piersi, stał się bardzo popularny. Coraz więcej mówi się o modyfikacji stylu życia, a także o ważności regularnych badań. Tworzone są duże narodowe programy, a w rozpowszechnianie informacji zaangażowanych jest wiele organizacji. Kampanie te kierowane są jednak w zdecydowanej większości do kobiet starszych bądź będących w grupie podwyższonego ryzyka. Niewiele jest natomiast działań dotyczących poszerzenia wiedzy młodych kobiet na tematy związane z nowotworami, stąd prawdopodobnie też w tak dużym stopniu respondentki zgłosiły taką potrzebę. Warto wspomnieć również, że podstawowym źródłem wiedzy na temat profilaktyki raka piersi były media.

\section{WNIOSKI}

Poziom świadomości studentek z zakresu czynników ryzyka i profilaktyki raka piersi wśród studentek wrocławskich uczelni można uznać za zadowalający, jednak uzależniony był on od wybranego kierunku studiów. Wiedza teoretyczna nie była wykorzystywana w praktyce. Niezależnie od profilu uczelni respondentki zgłosiły potrzebę prowadzenia kampanii na rzecz walki z rakiem w Polsce.

\section{PIŚMIENNICTWO}

1. Torre LA, Bray F, Siegel RL, Ferlay J, Lortet-Tieulent J, Jemal A. Global cancer statistics, 2012. CA Cancer J Clin 2015;65(2):87-108. doi: 10.3322/ caac. 21262.

2. Didkowska J, Wojciechowska U, Zatoński W. Nowotwory złośliwe w Polsce w 2012 roku. Warszawa: Ministerstwo Zdrowia; 2014. p. 7-8.

3. Knutson TP, Lange CA. Tracking progesterone receptor-mediated actions in breast cancer. Pharmacol Ther 2014;142:114-25.

4. May F. Novel drugs that target the estrogen-related receptor alpha: their therapeutic potential in breast cancer. Cancer Manag Res 2014,6:225-52. doi: 10.2147/CMAR.S35024.

5. Makowski M, Połać I, Pertyński T. Estrogeny a rak sutka. Prz Menopauz 2007;3:150-4.

6. Ślusarska B, Nowicki G, Łachowska E, Piasecka E, Marciniak A. Wiedza kobiet na temat profilaktyki raka piersi w wybranych uwarunkowaniach socjodemograficznych. Med Og Nauk Zdr 2016;22(1):59-65.

7. Cichońska M, Borek M, Krawczyk W, Maciąg D. Wiedza kobiet w zakresie zapobiegania nowotworom piersi i raka szyjki macicy. Acta Sci Acad Ostroviensis 2012;1:5-25.

8. Lewandowska A, Mess E, Laufer J. Profilaktyka raka piersi wśród kobiet. Onkol Pol 2011;14(3):131-4. 
9. Stanisławska J, Janikowska K, Stachowska M, Talarska D, Drozd-Gajdus E Szewczyczak M. Ocena wiedzy kobiet w zakresie profilaktyki raka piersi i raka szyjki macicy. Probl Hig Epidemiol 2016;97(1):38-44.

10. Wołowski T, Wróblewska P. Ocena wiedzy gdańskich studentek na temat profilaktyki raka piersi. Probl Hig Epidemiol 2012;93:347-9.

11. Ridan T, Berwecki A, Spannbauer A, Rubinkiewicz P, Mucha D. Ocena wiedzy i postaw studentów na temat profilaktyki raka piersi i mastektomii. Doniesienie wstępne. Cywilizacyjne zagrożenia zdrowia człowieka. Wyzwania dla edukacji i profilaktyki. Kielce: Wyd. Uniwersytet Jana Kochanowskiego w Kielcach; 2016.

12. Kalinowski P, Bojakowska U, Kowalska ME. Analiza wiedzy studentek Uniwersytetu Medycznego w Lublinie z zakresu epidemiologii raka piersi. Probl Pielęg 2014;22(2):147-53.

13. Paździor A, Stachowska M, Zielińska A. Wiedza kobiet na temat profilaktyki raka piersi. Now Lek 2011;80(6):419-22.

14. Woźniak I. Wiedza o schorzeniach nowotworowych narządów kobiecych i postawy kobiet wobec badań profilaktycznych. Probl Pielęg 2008;16(12):136-43.
15. Zych B, Marć M, Binkowska-Bury M. Stan wiedzy kobiet po 35. roku życia w zakresie profilaktyki raka piersi. Prz Med Uniw Rzesz 2006;1: 27-33.

16. Tkaczuk-Włach J, Sobstyl M, Jakiel G. Rak piersi - znaczenie profilaktyki pierwotnej i wtórnej. Prz Menopauz 2012;4:343-7.

17. Strojek K, Maślanka M, Styczyńska H, Zukow W. Zachowania prozdrowotne i stan wiedzy kobiet na temat profilaktyki raka piersi. J Educ Health Sport 2017;7(3):166-76. doi: 10.5281/zenodo.268299.

18. O'Malley MS, Fletcher SW. US Preventive Services Task Force. Screening for breast cancer with breast self-examination. A critical review. JAMA 1987;257:2196-203.

19. Łepecka-Klusek C, Jakiel G, Krasuska ME, Stanisławek A. Breast selfexamination among Polish women of procreative age and the attached significance. Cancer Nurs 2007;30:64-8.

20. Jassem J, Krzakowski M. Rak piersi. In: Krzanowki M, Warzocha K, editors. Zalecenia postępowania diagnostyczno-terapeutycznego w nowotworach złośliwych - 2013 r. T. 1. Gdańsk: Via Medica; 2013. p. 211-64. 